\title{
Inflation Dynamics and Fiscal Deficit in Nigeria: Examination of Causal Relationship
}

\author{
${ }^{*}$ Orji Uka Odim, ${ }^{2}$ Onyeze Clementina Ngozi and ${ }^{3}$ Edeh Lawrence \\ ${ }^{1}$ Department of Economics, Tansian University Umunya, Nigeria. \\ ${ }^{2}$ Department of Co-operatives and Rural Development, Faculty of Management Sciences, Enugu State \\ University of Science and Technology, Agbani, Nigeria. \\ ${ }^{3}$ Department of Accountancy, Tansian University Umunya, Nigeria.
}

\begin{abstract}
Government expenditure in Nigeria has consistently exceeded revenue for most of the years beginning from 1980. This paper investigates the causal relationship between inflation and fiscal deficit in Nigeria from 1970 to 2010. It was empirically continued that although fiscal deficit causes inflation, there was no feedback between inflation and fiscal deficit deflated by the GDP. The structural model of inflation revealed that, it takes about two years for the fiscal deficit to impact on inflation in Nigeria. The study concluded that what should be of paramount concern to policy makers as regards to inflation should not so much be the level of fiscal deficit but the sources of its financing as well as the absorptive capacity of the economy. Thus, policies to tame inflation should have inbuilt ability to increase the productive capacity of economy.
\end{abstract}

Keywords: real private investment, fiscal deficit, real interest rate, real exchange rate and inflation rate.

\section{Introduction}

The growth and persistence of fiscal deficits in both the industrialized and developing countries in recent times have brought the issue of fiscal deficits into sharp focus. The issues surrounding fiscal deficits are certainly not new, but the economic development of the past decade has rekindled the interest in fiscal policy issues. In the advanced countries, the growth of united states federal deficits on economic activities (Islam and Wetzel, 1991).

Government expenditure in Nigeria has consistently exceeded revenue for most of the years beginning from 1980. The symptoms of such fiscal imbalance one of course, budget deficits. While budget deficits are nothing new in the country's history, the recent size of the deficit has been a cause of concern to many people including academics, policy makers, and investors. It is, however, pertinent to note that much of the debates over the deficits have been more related to the effects of unacceptable large deficits rather than with the causes of the deficits. For example, higher interest rates, real exchange rate depreciation increased public spending is frequently mentioned. Others point the direct relationship between fiscal deficits and inflation, with the causal link generally assumed to be deficits financing by means of credit creation through the banking system. Even though convincing empirical evidences pointing to a significant relationship between deficits and these variables are few, there has been renewed interest on the issues deficits reduction in recent times. However, proposals that do not address the basic causes of deficit growth will not likely achieve the desired results of deficit reduction on a sustainable basis.

\section{Statement of the Problem}

Ten years 'between' (1960-1970), inflation reached double-digit mark. It was only in 1966 and 1970 that it was as low as 10.27 percent and 13.8 percent respectively. Hence, these two periods could generally be described as one modest inflation rate. But in 1966 fiscal deficit showed a decreased of 39.2 per cent. It became alarming in 1967, 1969 and 1970 with 163.8 percent, 69.9 percent and 15552.8 percent, respectively. Between 1967 and 1970, the size of fiscal deficit as expressed in millions of naira did not. However, exceed three digit levels (Adeyeye and Fakiyesi 1980).

Inflation in the oil boom reached double digit except for 1972 and 1973 when the rates were 3.2 percent and 5.4 percent, respectively. The rates of inflation were 15.6, 34.4, 23.7, and 15.7 percent in 1071, 1975, 1976 and 1977, respectively. In the recent years it shows that inflation rates are still revolving around double digits. For instance, in $2000,2001,2002,2003,2004,2005,2006$ and 2007 with 6.9\%, 18.9\%, 12.9\%, $14.0 \%, 15.0 \%, 17.9 \%, 12.5 \%$ and 5.4 respectively, while fiscal deficit in those years have been on increase and decrease with no stability. Such instability in those years is like $103.8 \mathrm{~m}, 221 \mathrm{~m}, 301.4 \mathrm{~m}, 202724.7 \mathrm{~m}, 172.6 \mathrm{~m}$, 161406m, 101397.5 and 117.2 respectively from CBN Statistical Bulletin; Volume 16 (2007).

In the less developed countries, Nigeria inclusive, fiscal deficits have been blamed for much of the debt crisis, high inflation and poor economic growth (Islam \& Wetzel 1991). 
As easterly and Schmidt-Hebble (1993) put it, attempts to regain stability at the macro-level in the LDCs through fiscal adjustment achieved little or no success, raising questions about the macroeconomic consequences of public deficits and fiscal stabilization. Based on these premise, following research questions which are important in the study of fiscal deficits and inflation dynamics in Nigeria were raised. These questions are:

Do fiscal deficits causes inflation or is it inflation that causes fiscal deficits?

To what extent is the effect of fiscal deficits on investment decision in Nigeria?

\section{Objective of the Study}

The main objective of this paper is to investigate the causal relationship between inflation and fiscal deficits in Nigeria. Elaborately, the paper seeks

1. To critically analyze the causality linkage between fiscal deficit and inflation in Nigeria.

2. To empirically determine the effects of fiscal deficit on investment decision in Nigeria.

Statement of the Hypothesis

This research work is guided by the following hypothesis:

$\mathbf{H}_{01}$ : there is no causal linkage between fiscal deficit and inflation in Nigeria.

$\mathbf{H}_{\mathbf{0 2}}$ : the effect of fiscal deficits on investment decision in Nigeria is statically insignificant.

\section{Literature}

Inflation can vividly be defined as a general and continuous increase in prices of goods and services. For the purpose of this work, the causes of inflation would be discussed under the contending views the monetarists and structuralists. The monetarist argued that inflation is caused by excessive monetary growth. That is to say that the rate of increase in the money stock is substantially in excess of the rate of growth of real output. This monetarist argument was earlier advanced by Friedman (1956, 1960 and 1971). To him, changes in money supply have been seen to cause changes in prices. It follows, therefore, that an increase in money supply is likely to cause an increase prices, and hence inflation. Inflation in the Cagan model is caused specifically by expansion in the money supply and there is no feedback.

Fiscal deficit arise because public spending rises while revenue remain unchanged, or tax revenue falls while public spending remains unchanged, or tax revenue falls while public spending rises. A commonly observed phenomenon in most developing countries is that, the public sector plays a dominant role in initiating and financing economic growth. The resultant growth in public spending is expected to be financed by public revenue from taxes and non tax source but the revenues always lay behind the level of public spending, leaving large deficits in the focus.

In Nigeria, there have been several studies for various time periods on the causes of inflation, for instance, Oyajide (1972), Akinnifesi (1984), Adeyeye and Fakiyesi (1980), Osakwe (1983) and Asogu (1991), attempted empirically to ascertain the causes of inflation in Nigeria Oyajide (1972) made empirical enquiry into the impact of deficit financing on inflation and capital formation. He related domestic money supply to inflation using fisher's type of equation. Since there is a direct correlation between general price level measures of deficit financing over the 1957-1970 time period, he concluded that les emphasis on deficit financing may limit the growth of price inflation. In Akinnifesi (1984) factors such as changes in money supply, lagged changes in money supply, credit to government by the banking system, government deficit expenditure, industrial production and food price indices were used in empirical estimation. The study showed that chages in the above factor jointly explained inflationary tendencies in Nigeria. The study, however, emphasized that increases in government expenditure financed by monetization of oil revenue and credit from the banking system were responsible for the expansion of money supply, which in turn, with a lagged-in-effect contributed immensely to inflationary tendencies.

Adeyeye and Fakiyesi (1980), estimated and tested the hypothesis that the main factor responsible for instability of prices and inflationary tendencies in Nigeria has been government expenditure. Using annual timeseries data, spanning 1960-1977, they tested hypothesis that the rate of inflation in Nigeria is linearly related to the rate growth of money stock, government expenditure, especially monetization of foreign exchange form oil exports. The results established some significant positive relationship between inflation rate and growth in bank credit, growth of money supply and growth in government expenditure, while the relationship with growth of government revenue was uncertain.

Osakwe (1983), attempted to verify the amount of government expenditure which affect money supply in the ten year period 1970-1980, using quarterly data. Significant statistical relationship obtained from the analysis showed strong relationship between increases in net current expenditure and growth in money supply on the one hand, and growth in money supply and inflation on the other hand. Further increase in money wage rates and money supply (with lag-in-effect) were identified as the two most important factors which influenced the government of prices during the period. 
Asogu (1991) considered factors such as money supply, its lagged values, domestic credit, real output, net export domestic credit, real output, net exports, and net government expenditure in a single equation model. The results showed that the money supply variable and its lag were not significant at last when annual data were used in the estimation. In addition, changes in real income were significant and had an inverse relationship with the rate of inflation. Further, domestic credit was not significant, while government expenditure even though statistically significant had the wrong sign.

Egwaikhide et at (1994) in a study titled "exchange rate depreciation, budget deficit and inflation: the Nigerian experience" examined the quantitative effects of exchange rate depreciation on inflation, government revenues and expenditures, and money supply in Nigeria. The findings that domestic money supply, real output, the shadow price of exchange rate (the parallel market exchange rate) and more recently official exchange rate are the proximate causes of inflation in Nigeria. In a related study Ariyo and Raheem (1991) made an in-dept investigation of the impact of fiscal deficit on the level and direction of economic growth and development as might be reflected in the behaviour of key macroeconomic indicators such as current account balance, government investment, private investment, inflation, interest rate, external and internal debts profiles, etc. the findings also confirmed a direct relationship between fiscal deficit and inflation. However, none of these studies tested for causality between fiscal deficit and inflation.

With the oil sector contributing over 90 percent of foreign exchange earnings and 80 percent of government finances generally, the problem of unsustainable level of fiscal deficits, which the national has been experienced for some years, may undermine the implementation of deregulation of the downstream sector. Fiscal deficits financed through borrowing from domestic sources would continue to have inflationary undertones and inevitably affect the rate of foreign exchange at which petroleum products are being imported.

One implication is that the prices of petroleum product would be changing with the movements in the foreign exchange and inflation rates. The independent marketers would therefore demand continuous price review embarrassment of the government, which each prices review for petroleum products would lead to a new round of inflation.

Obviously, deregulation of importation of petroleum products without domestic production base can only lead the nation to a vicious circle of budget deficits, inflation, pump price increases, and inevitably a growing number of the poor.

Diamond (2001) provide a review of the relationship between fiscal deficits and different policy target such as the rate of growth, inflation and the current account balances respectively. Their results confirm the presence of a high correlation between budget deficit and inflation rates, which is the main focus of our study in the context of Barro regressions. The presence of this correlation leads them to study fiscal policy as being endogenous. Thus, government budget deficit was found to be consistently correlated with inflation rates.

The repeated failure of disinflation programmes led to private agent's lack of confidence in the ability of government to persevere in reform efforts and to maintain a consistent set of policies overtime. A tradition of failed stabilization attempts suggests that the credibility problem that any anti-inflation program must face become more acute, underlining further the downward rigidities that characterize the inflationary process. The most direct ways policy makers can use to publicize their intention to refrain from adopting inflationary policies is, of course, to announce an inflation target. But given that inflation rate is not under the direct control of the authorities, an inflation target not linked to specific policy commitments that can be readily monitored will not be credible to private agents. Establishing the credibility of macroeconomic policies at the beginning of disinflation programme is therefore vital (Agenor and Montiel, 1996). This afore-stated analysis explains the undercurrent when NEEDS was launch in 2004 and the accompanying appropriation bills, particularly the 2004 and 2005 bills, as overall macroeconomic policy.

The fiscal deficit as at September 2004 stood at 1.5 percent of GDP well within the 2.1 percent target. The moving average inflation for the year was 19.1 percents, the 12 month on - month or - year on year inflation was trending downwards. June to June inflation was at 14.1 percent and July to July was 10.9 percent, August to August, 13 percent with downward trend and in spite of the September like due to higher oil prices, the low double digit inflation $(10,11$ percent) targeted for the year was attained. With 81 percent of the capital budget implemented within three quarters of the budget year, and a relatively stable exchange rate, Nigeria was set for a clear break from the imprudent macroeconomic policies of the past (Obasanjo; 2005 IMF Staff Mission 2005). Particularly, the IMF staff mission observed some development in 2004 and early 2005:

Generally, it can be said that there is a renewed depositor's confidence in Nigeria banks today with the emergence of stronger and more reliable banks. Data collection for monetary policy management, particularly the CBN's analytical balance sheet data has been transformed from a two month lag to a daily production, thereby providing a better handle on the growth rate of reserve money. In effect, several agenda are being pursued with a view to reforming the payment system, currency restructuring; deepening the money market and institutionalizing greater transparency and good corporate governance system in banking industry. Undoubtedly, having a monetary policy framework that does not only follow but builds on recent historical experience around 
the world would vastly improve economic stability and growth. But implementing such a policy would require further institutional and operational changes. For instance, the credibility of the programme would be enhanced, if the preserves on the central bank to finance the government budget deficit were reduced. Between 1989 and 2002 , the CBN accommodated high fiscal deficits in the past, averaging 5 percent of GDP. These deficits were largely financed through the banking system. In 2003, monetary base growth was 26 percent compared with a target of 15 percent. This high rate of money growth fuelled inflation. In 2003 alone, the inflation rate increased to 24 percent from 12 percent in 2002 Taylor (2004).

\section{Research Methodology}

To merely assume that since the size of fiscal deficit over the years has continued to increase, and the inflation rate, on the average, during the study period has remained double- digit, then fiscal deficit and inflation simultaneously induce each other is rather simplistic. In order to investigate the relationship between inflation and fiscal deficits, we shall use the granger causality test suggested by Granger (1969). Here, we estimated an unrestricted equation with lags of particular variables formulated individually and then test he joint significance of each variables. Therefore, we specified two inflations with fiscal deficit and fiscal deficit as dependent are their respective lags as independent variables as follows:

Model 1 Objectives 1

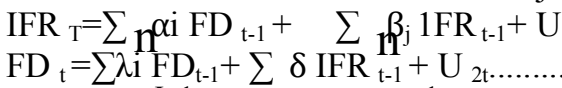

Ofi ${ }^{1}$ the above infoirntation, where $\alpha_{i}, \beta_{j}, \lambda_{i}$, and $\delta_{i}$ are parameter estimates; $U_{1 t}$ and $U_{2 t}$ are uncorrelated. In the abovejflamework, IFR does not Granger cause FD if $\beta_{1}=\beta_{2} \ldots \ldots \beta_{n}=0\left(\beta_{n}=0\right)$.

Similarly, for equation (ii), fiscal deficit does not Granger cause inflation if non of $\alpha_{\mathrm{I}}$ is statistically different from zero (i.e. $\alpha, \neq 0$ ).

Furthermore, we shall make use of a single linear specification model for second objective. Thus, we specified as follows:

$\mathrm{PINN}=\mathrm{F}(\mathrm{FD}, \mathrm{RIR}, \mathrm{RER}, \mathrm{IFR}$, and TRD) (iii) where

$\mathrm{RPINV}=$ real private investment, $\mathrm{FD}=$ fiscal deficit, $\mathrm{RIR}=$ real interest rate $\mathrm{RER}=$ real exchange rate, $\mathrm{IFR}=$ inflation rate, $\mathrm{TRD}=$ trend value over-time.

Thus, transforming equation (iii), we can econometrically state them as:

Model (2) Dbjectives (2)

RPINV $=\alpha_{0}+\alpha_{1}$ FD $+\alpha_{2}$ RIR $\alpha_{3}$ RER $+\alpha_{4}$ IFR $+\alpha_{5}$ TRD $+\mathrm{U}$

Data

This result of Granger causality for model 1 is presented below. The parameter estimates were subjected to statistical and econometric test. Hence, the hypothesis to be tested shall be evaluated based on the following analysis. The results of the estimated model are presented in the table below;

\section{Decision Rule}

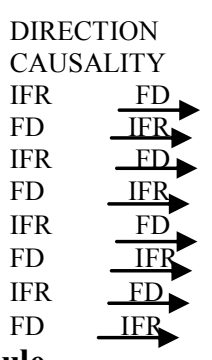

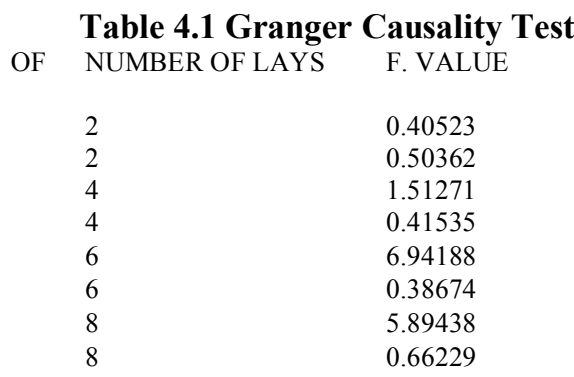

DECISION
Do not reject
Do not reject
Do not reject
Do not reject
Reject
Do not reject
Reject
Do not reject

If the computed F-value exceeds the critical $\mathrm{F}$ value at $5 \%$ level of significance. We reject the null hypothesis if Fcal $>$ Ftab, otherwise, accept $\alpha$

Conclusion: since F-tab $<$ fcab, there is no reverse causation from higher (FD) to inflation rate (IFR), since the F-value is statistically insignificant.

On the other hand, this result suggests that the direction of causality is from higher inflation rate to larger fiscal deficits, since the estimated outcome of the Granger test is sensitive to number of lags introduced in the model.

Presentation of Regression Result

Table 4.2: Model 2

$\begin{array}{lllll}\text { VARIABLES } & \text { COEFFICIENTS } & \text { STD-ERROR } & \text { T-STATISTIC } & \text { PROB. } \\ \text { CONSTANT } & -11233.14 & 28212.85 & -0.398157 & 0.6932 \\ \text { FD } & -0.128251 & 0.041818 & -2.570242 & 0.0150 \\ \text { RER } & 134.8486 & 12.90817 & 10.44676 & 0.0000 \\ \text { RIR } & -6585.938 & 3022.314 & -2.179105 & 0.0368\end{array}$




$\begin{array}{lllll}\text { IFR } & -6221.638 & 2929.192 & -2.124019 & 0.0415 \\ \text { TRE } & 8811.170 & 2711.425 & 3.249646 & 0.0027\end{array}$

$\mathrm{R}^{2}=0.955067$, Durbin - Watson stat. 1.267506

$\mathrm{F}-\mathrm{Stat}=136.0336 \mathrm{R}^{-2}=0.802568$.

\subsection{Evaluation of Results}

From the result in (table 4.2 above) it is observed that while the constant term, FD, RIR, IFR, and TRE conformed to their "a-priori expectations" RER did not. The implication is that a unit increase in real exchange rate would on the average increase the value of real private investment by $13484.86 \%$ whereas, a unit increase in both FD, RIR, IFR, and TRE would decrease real private investment by $12.8251 \%, 658593.8 \%, 622163.8 \%$ and $881117.0 \%$ respectively.

\section{ECONOMETRIC (SECOND ORDER) CRITERIA}

Stationary Test

The units root test for stationary is applied using the augmented Dickey-Fuller (ADF) test.

Decision Rule

Reject $\mathrm{H}_{0}$ if the absolute values for the calculated ADF for any of the variables are greater than the absolute of the $5 \%$ critical values.

UNIT ROOT TEST

$\begin{array}{llll}\text { Variable } & \text { ADF - test } & \text { Mackinnon critical value 5\% } & \text { Order of integration } \\ \text { RPINV } & -4787076 & -2.9446 & \text { I }(1) \\ \text { FD } & -5.230116 & -2.9422 & \mathrm{I}(0) \\ \text { RER } & -3.724639 & -2.9446 & \mathrm{I}(1) \\ \text { RIR } & -3.179480 & -2.9422 & \mathrm{I}(0) \\ \text { IFR } & -3.052962 & -2.9422 & \mathrm{I}(0)\end{array}$

From the above table, we see that the time series variables are stationary at different order. Their absolute values are greater than their critical values at $5 \%$ level, so we conclude that the variables are stationary.

\section{Co-integration Test}

We there run their linear combination at the level from constant and obtained their residual, which was then subjected to unit root test of stationary. However, the result shows that there is co-integration, since the residual is stationary at $5 \%$ critical values.

\section{Test for Multi-collinarity}

Case I: if the $r^{2}$ from the correlation matrix is excess of 0.8 , we conclude that there is presence of multicollinearity.

Case II: if the $r^{2}$ from the correlation matrix is less than 0.8 , we conclude that there is no multi-collinearity.

$\begin{array}{lll}\text { Variable } & \text { Correlation coefficient } & \text { Conclusion } \\ \text { FD \& RER } & 0.004837 & \mathrm{NM} \\ \text { FD \& RIR } & -0.009525 & \mathrm{NM} \\ \text { FD \& IFR } & -0.079495 & \mathrm{NM} \\ \text { FD \& RIR } & -0.242925 & \mathrm{NM} \\ \text { RER \& RIR } & 0.403457 & \mathrm{NM} \\ \text { RER \& IFR } & -0.236741 & \mathrm{NM} \\ \text { RER \& IRE } & 0.757223 & \mathrm{NM} \\ \text { RIR \& IFR } & -0.913069 & \mathrm{NM} \\ \text { RIR \& TRE } & 0.254917 & \mathrm{NM} \\ \text { IFR \& TRE } & 0.066196 & \mathrm{NM}\end{array}$

Where NM stands for no multicollinearity among variables

\section{Test for Autocorrelation}

Here, we shall test for the presence of autocorrelation in the estimated model. Durbin-Watson test can be used to determine the autocorrelation.

$\begin{array}{lll}\text { Null hypothesis } & \text { Decision rule } & \text { Condition } \\ \text { No positive autocorrelation } & \text { Reject } & \mathrm{U}<\boldsymbol{\partial}<\boldsymbol{\partial}< \\ \text { No positive autocorrelation } & \text { No decision } & \mathbf{\partial L} \leq \mathbf{\partial} \leq \mathbf{\partial u} \\ \text { No negative " } & \text { Reject } & 4-\boldsymbol{\partial} \mathrm{L}<\boldsymbol{\partial}<4 \\ \text { No negative " } & \text { No decision } & 4-\boldsymbol{\partial u} \leq \mathbf{\partial} \leq 4-\boldsymbol{\partial L} \\ \text { No positive or negative autocorrelation } & \text { Do not reject } & \mathbf{\partial u}<\boldsymbol{\partial}<4-\boldsymbol{\partial L}\end{array}$

\section{Decision Rule}

Reject $\mathrm{H}_{0}$ if $\partial \mathrm{u}<\partial<4-\partial \mathrm{L}$ which implies no autocorrelation otherwise accept $\mathrm{H}_{0}$

$\partial \mathrm{L}=1.261, \partial \mathrm{u}=1.722, \partial^{*}=1.267506$

Where

$\partial \mathrm{L}$ means Durbin - Watson lower limit

$\partial \mathrm{u}$ means Durbin - Watson lower limit 
Since $1.261 \leq 1.267596 \leq 1.722$, we conclude that there is no positive autocorrelation.

\section{Test for Heteroscedasticity}

This test was carried out using white general heteroscedasticity test (with no cross terms). The test asymptotically follows; a chi-square distribution with degree of freedom equal to the number of regression (excluding the constant)

The model tested can be stated as;

$\mathrm{U}_{1}=\propto_{0}+\propto_{1}(\mathrm{FD})+\propto_{2}(\mathrm{RER})+\propto_{3}(\mathrm{RIR})+\propto_{4}(\mathrm{IFR})+\propto_{5}(\mathrm{TRE})+\propto 6(\mathrm{FD})^{2}+\propto_{7}(\mathrm{RER})^{2}+\propto_{8}(\mathrm{RIR})^{2}+\propto_{9}$ $(\mathrm{IFR})^{2}+\propto_{10}(\mathrm{TRE})^{2+} \propto_{11}$ (FD) (RER) (RIR) (IFR) (TRE) $+\mathrm{V}_{1}$

\section{Decision Rule}

If calculated value exceeds the critical ch-square value at $5 \%$ level of significance, we accept. I.e. Reject $\mathrm{H}_{0}$ of $\mathrm{x}^{2}$ cal $>\mathrm{x}^{2}$ tab, otherwise accept. The calculated chi-square $\mathrm{x}^{2}$ cal at 9 degrees of freedom is gotten as follows

$\mathrm{NXR}^{2}=38 \times 0.239234=8.74$.

Where $\mathrm{N}=$ numbers of observation

$\mathrm{R}^{2}=\mathrm{R}^{-2}$ of the antilliary regression

The tabulated chi-square $\mathrm{X}^{2} \mathrm{cal}<\mathrm{X}^{2}$ tab at $\mathrm{X} 20.005=16.92$

Conclusion

Since the $\mathrm{X}^{2}$ cal $<\mathrm{X}^{2}$ tab that is $8.74<16.92$, we accept our null hypothesis and conclude that the variance of the error term is homoscedasticity i.e. the residuals have a constant variance.

\section{Test for Specification Error}

This test was carried out using Ramsey's general test to check if the model is correctly specified.

Decision Rule

$\begin{array}{lll}\text { VARIABLES } & \text { F-STATISTIC } & \text { F-VALUE } \\ \text { FITTED }^{\wedge} & 8.057737 & 2.69\end{array}$

Reject H0: if $\mathrm{F}^{*}$ (Fcal) $>\mathrm{F} 0.05$ or Accept H1: if $\mathrm{F}^{*}$ (Fcal) $<0.05$

$\mathrm{Fcal}=8.057737 \quad \mathrm{~F} \alpha(4,34)=2.87$

Thus, since Fcal $>$ Ftab i.e. $8.057737>2.69$, reject the null hypothesis and accept that the alternative hypothesis thus, conclude that the model is correctly specified.

Evaluations of Research Objectives and Working Hypothesis

In the first objective, we discovered that there is a unidirectional causality from fiscal deficit to inflation in Nigeria and there is no feedback effect. In the second objective, we discovered equally that fiscal deficit, real interest rate and inflation rate have negative effect on the real private investment while real exchange rate has positive effect etc.

\section{Summary of the findings}

The research work has been specified and estimated a model on the empirical investigation of causal relationships between fiscal deficits and inflation dynamics over the period 1970 to 2007 in Nigeria. Two models were specified, with the first just on inflation rate and fiscal deficit alone, while in the second model. The first model were estimated using Granger causality test while the second model uses the method of OLS in order to estimate the parameters measured in elasticity.

In other words, from the result of model in table 4.1, it is apparent that fiscal deficits Granger cause inflation while due to the sensitivity of Granger causality test to the number of lags introduced in the model, inflation Granger causes fiscal deficit. This means that there is feedback or bi-directional relationship between fiscal deficit and inflation. The adjusted $\mathrm{R}^{2}\left(\mathrm{R}^{2}\right)$ of 0.802568 further reveals that real interest rate, real exchange rate, inflation rate, fiscal deficit and trend over time accounts for a large amount of variation in real private investment. The economic, statistical and econometric criteria such as autocorrelation test, multi co-linearity test, heteroscedasticity test, unit root and finally co-integration were adopted. The co-integration test was adapted using the animated dickey fuller (ADF) test to investigate whether the long run relationship exists among the variables. Actually, all the variables were stationary at order one to ascertain the long-run equilibrium relationships of the series in the model.

\section{Policy Implication}

The results of our analysis have great policy implication which the federal Government of Nigeria cannot afford to over look. This is because; large deficits are caused by increased government expenditures results in higher deficits, and higher deficits turn causes inflation, then government expenditure can cause inflation. This shows that the inflationary effect of government deficits depends on the means by which the deficit is financed and the impact of the deficit on aggregate demand. 
Therefore, the policies targeted at inflationary control could be best achieved it is aimed at fiscal deficits reduction. Consequently, it could be concluded that in Nigeria, that should be paramount concern to policy makers as regards inflation should not so much be level of fiscal deficits but the sources of its financing as well as the absorptive capacity of the economy.

\section{Conclusion}

The extent of the burden of inflation rate and fiscal deficit depends on their impact on the economy. When inflation rate and deficits increase overtime, it will have an adverse effect on the economy. This long run effect has been established in this research through the co-integration test on the residual which are stationary at order one. There is need to emphasize on the mode of financing deficit and direction of such deficit spending. In Nigeria, deficits are largely financing by the CBN, a financial channel inimical to the healthy performance of the macroeconomic variable of economy.

Based on this, Prof. C.C Soludo, the then CBN governor said "we are trying to achieve a tightening monetary policy (single digit) and ensuring we do not allow unnecessary deficit financing by the government which has been the bane of our economy in the past" he said also, "we have been trying to put this in place by making the especially when it is financed by high powered money, by the central Bank. And of course, while we are not insisting that the government should not have a deficit, we are saying that the deficit should not be financed from the CBN resources, because this in itself is not inflationary"

Summarily, this study concludes that what should be of paramount concern to economist and policy makers as regard to economic growth should not be on the level of fiscal deficit but on the sources of financing such deficit, existing macroeconomic aggregate (inflation, unemployment, debt stuck recession, propensity to import, exchange rates and so on) and as well as the absorptive capacity of the economy.

Lastly, the policies to tame such fiscal deficit must have inbuilt stabilizers that will not disrupt already existing economic conditions but rather increase the productive capacity of the economy in order to ensure a viral and sustainable economic in Nigeria.

\section{Policy Recommendations}

From our findings, inflation is a serious macroeconomics problem in Nigeria, so certain measures must be considered in combating inflation rate in Nigeria, the main policy implication of this study implicitly derives from the general observation that most economic policy instruments adopted by government are contingent upon the nature of objective being pursued; we therefore make the following recommendations.

1. Government should check the level of deficit for effective control of inflation rate in Nigeria. The need arises because increase in fiscal deficit increases money supply which positively effects inflation rate.

2. Government should as a matter of urgency and importance adopt fiscal management actions that aim at minimizing borrowing and capable of reducing fiscal deficits that often result in large chunk of transfer payment, and extra budgetary expenses of questionable viability.

3. The "tending" profile of fiscal deficit has shown the tendency to move upwards but in unstable manner. This is as a result of social forces, most predominantly unplanned change in government regimes, policies, schemes and sudden shocks.

4. The federal Government can also adopt a Medium Term Expenditure Framework (MTEF) that will help manage the budgeting process in the economy. This is because some of the ministries inflate their budget proposals in order to embezzle money, which in the long run causes inflation in the country. So ministries budget should only be approved if the ministry can produce all increase revenue that is greater than the budget proposal.

5. More importantly, government should direct all the borrowing to the productive sectors of the economy. That is, if they can use the borrowing for the provisions of infrastructural facilities, surplus effects will outrun the deficit in economy. In summary, government should adopt policies mix taking into consideration the speed of adjustment, length of transmission and the magnitude of response. The income and debt management policy are to be adopted to reduce the effect of interest - on - debt on government spending and private investment, promote the regime of management flexible exchange rate.

\section{References}

[1]. Ariyo, A. and M.I Raheem (1991): Effect of Fiscal Deficit in Nigeria” Report of a Research Study Sponsored by AERC, Nairobi.

[2]. Ariyo, Raheem M.I. (1991): Effect of Fiscal Deficit in Nigeria" (1991). Report of a Research study Sponsored by AERC, Nairobi.

[3]. Central Bank of Nigeria (2007), Statistical Bulletin. Volume 18, December.

[4]. Dornbush, R. and S. Fisher (1991): "Moderate Inflation” Working papers Fisher S. (WPS), No. 807, Washington D.C: The World Bank, Office of the Vice President, Development Economics.

[5]. Easterly, Schmidt- Hebbel K. (1993); "Fiscal Deficits and Macroeconomic Performances in Developing Countries"

[6]. Egwaikhide, F.O. et al (1992): "Exchange Rate Depreciation, Budget and Deficit and Inflation: the Nigeria Experiences" the AERC, Nairobi.

[7]. Fisher, and Easterly W. (1990): “The Economics of Government budget constraint". World Bank Research Observer Vol. 5 No. 2.

[8]. Gujarratti, N. Damodar (2004) Basic Econometrics fourth Edition New York: McGraw Hill Inc. 
[9]. Heller. P. S. (1980): "impact of inflation of fiscal policy in developing countries" IMF staff papers Vol. 39 No. 3.

[10]. Humphery, T. M. (1986) "Essays on Inflation" Federal Reserve Bank of Rehmond, Rechmond, Virginia.

[11]. Islam, R. and Wetzel D. (1991) The Macroeconomics of Public Sector Deficits: The case of Ghana. Working Papers (wps) no. 672, Washington DC. The World Bank Policy Research and External Affairs Department.

[12]. Kiss, G.P. Szapany G. (2000), Fiscal Adjustment in the Transition Process: Hungary, 1990-1999, "Post-soviet Geography and Economics", Vol. 41 No. 4. Pp 223-264.

[13]. Luis Catao and Macro E. Terrons (2003) "Fiscal Deficits and Inflation" IMF Working Papers.

[14]. Miller, J. P. (1983): "Higher Deficit Policy Leads to Higher Inflation” Federal Reserve. Bank of Minneapolis- Quarterly Review, winter.

[15]. Mordi C. N. O. et al (2006) "Proceedings of the Fifteenth Annual Conference of the Research and Statistics Offices Held at Zaranda Hotels, Bunchi State: Inflation targeting in. Nigeria. Report of Research Study Sponsored by Central Bank of Nigeria.

[16]. Olusanja E. Olusanye and Rasheed Oyaromade (2008) "Modeling the Inflation Process in Nigeria" Report of a Research study Sponsored by AERC, Nairobi. 